\title{
Ion-Exchange in Glass-Ceramics
}

\author{
George H. Beall', Monique Comte ${ }^{2}$, Matthew J. Dejneka ${ }^{1}$, Paulo Marques$^{2}$, \\ Philippe Pradeau ${ }^{2 *}$ and Charlene Smith ${ }^{1}$ \\ ${ }^{1}$ Corning Incorporated Science and Technology Division, Corning, NY, USA, ${ }^{2}$ Corning S.A.S, Avon, France
}

OPEN ACCESS

Edited by:

Joachim Deubener,

Clausthal University

of Technology, Germany

Reviewed by:

Francisco Muñoz,

Spanish National

Research Council, Spain

Chao Liu,

Wuhan University

of Technology, China

*Correspondence:

Philippe Pradeau

pradeaup@corning.com

Specialty section:

This article was submitted

to Glass Science,

a section of the journal

Frontiers in Materials

Received: 14 June 2016 Accepted: 03 August 2016 Published: 23 August 2016

Citation:

Beall GH, Comte M, Dejneka MJ, Marques $P$, Pradeau $P$ and Smith $C$ (2016) Ion-Exchange in

Glass-Ceramics.

Front. Mater. 3:41.

doi: 10.3389/fmats.2016.00041
In the past few years, ion-exchange (IOX) in glasses has found a renewed interest with a lot of new development and research in industrial and academic labs and the commercialization of materials with outstanding mechanical properties. These glasses are now widely used in many electronic devices, including hand-held displays and tablets. The exchange is generally conducted in a bath of molten salt below the transition temperature of the glass. The exchange at the surface of an alkali ion by a bigger one brings compressive stress at the surface. The mechanical properties are dependent on the stress level at the surface and the depth of penetration of the bigger ion. As compared to glasses, glass-ceramics have the interest to display a wide range of aspects (transparent to opaque) and different mechanical properties (especially higher modulus and toughness). There has been little research on IOX in glass-ceramics. In these materials, the mechanisms are much more complex than in glasses because of their polyphasic nature: IOX generally takes place mostly in one phase (crystalline phase or residual glass). The mechanism can be similar to what is observed in glasses with the replacement of an ion by another in the structure. But in some cases this IOX leads to microstructural modifications (for example, amorphization or phase change). This article reviews these IOX mechanisms using several transparent and opaque aluminosilicate glass-ceramics as examples. The effect of the IOX in the various glass-ceramics will be described, with particular emphasis on flexural strength.

Keywords: ion-exchange glass-ceramics, mechanical properties, b-quartz solid solution, b-spodumene solid solution, nepheline, microstructures, $\mathrm{X}$-ray diffraction

\section{INTRODUCTION}

In the past few years, ion-exchange (IOX) in glasses has found a renewed interest with a lot of new development and research in industrial and academic labs and the commercialization of materials with outstanding mechanical properties (Varshneya, 2010; Aaldenberg et al., 2016). These glasses are now widely used in many electronic devices, including hand-held displays and tablets (Glaesemann et al., 2012). They find also applications in the architectural and automotive markets.

One can imagine new applications using glass-ceramics instead of glasses as a much wider range of aspect can be obtained. Glass-ceramics display various opacity and color: from opaque to transparent and for opaque materials, including white to black and a range of colors. Glass-ceramics can present also improved mechanical properties as compared to glasses with especially higher toughness and modulus.

Ion-exchange is generally conducted in a bath of molten salt. The exchange from the surface of an alkali ion in the glass or glass-ceramic by a bigger one from the bath leads to compressive stress at the surface and because of the concentration distribution to a stress profile through the 
sample. The mechanical properties are dependent on the stress level at the surface (CS) and the depth of penetration of the bigger ion (Gy, 2008).

If the IOX in glasses has been the subject of many studies, there has been little research on the IOX in glass-ceramics. In these materials, the mechanisms are much more complex than in glasses because of their polycrystalline nature: IOX generally takes place mostly in one phase (crystalline phase or residual glass). In some cases, the mechanism is similar to what is observed in glasses with the replacement of an ion by another in the structure; while in other cases, this IOX leads to microstructural modifications (for example, amorphization or phase change of a crystalline phase).

These different mechanisms have been observed at Corning studying IOX in different transparent and opaque aluminosilicate glass-ceramics. This research is going to be presented here with a special emphasis on the impact of IOX on microstructure and mechanical properties, especially flexural strength. The different systems and corresponding IOX mechanisms are summarized in Table 1.

Several papers demonstrate a significant increase of the modulus of rupture of glass-ceramics after IOX. Most of them do not detail the IOX mechanisms.

For example, in 1967, Beall et al. (1967) have shown that the modulus of rupture of $\beta$-quartz glass-ceramic can be multiplied by a factor of 5 replacing $\mathrm{Li}^{+}$by $\mathrm{K}^{+}$or $\mathrm{Mg}^{2+}$ by $2 \mathrm{Li}^{+}$. More recently, Takeuchi et al. (1997) have studied IOX in ferrules made of $\beta$-spodumene glass-ceramic and shown that replacement of $\mathrm{Li}^{+}$ by $\mathrm{Na}^{+}$leads to a bending-strength of about $500 \mathrm{MPa}$, which is similar to that of an alumina ferrule and that a bendingstrength of $310 \mathrm{MPa}$ is maintained after scratching. Berthier da Cunha et al. (2007) have shown that IOX in a $\mathrm{Na}_{4+2 \mathrm{x}} \mathrm{Ca}_{4-\mathrm{x}} \mathrm{Si}_{6} \mathrm{O}_{18}$ $(0<\mathrm{x}<1)$ glass-ceramic is associated with a significant increase of hardness and indentation fracture toughness. A modest but significant increase of strength associated with an increase of

TABLE 1 | Different strengthening mechanism obtained with IOX in glassceramics (g.c.).

\begin{tabular}{|c|c|c|c|}
\hline \multicolumn{2}{|l|}{ Mechanism } & \multirow{2}{*}{$\begin{array}{l}\begin{array}{l}\text { Examples } \\
\text { presented here }\end{array} \\
\text { Black fusion } \\
\text { formable g.c. }\end{array}$} & \multirow{2}{*}{$\begin{array}{l}\text { Aspect of the } \\
\text { glass-ceramic } \\
\text { Black, opaque }\end{array}$} \\
\hline \multirow[t]{4}{*}{$\begin{array}{l}\text { Typical IOX } \\
\text { (larger ion } \\
\text { for smaller) }\end{array}$} & $\begin{array}{l}\text { In the } \\
\text { residual } \\
\text { glass }\end{array}$ & & \\
\hline & & & $700^{\circ} \mathrm{C}-4 \mathrm{hr}$ \\
\hline & $\begin{array}{l}\text { In the } \\
\text { crystals }\end{array}$ & Spodumene g.c. & White, opaque \\
\hline & & $\begin{array}{l}\text { Mg-rich } \beta \text {-quartz } \\
\text { s.s. g.c. }\end{array}$ & $\begin{array}{r}\text { Transparent Crystal!ization and Ch } \\
\text { Stuffed \&-Quar }\end{array}$ \\
\hline
\end{tabular}

Surface Li-rich $\beta$-quartz Transparent amorphization s.s. g.c.

Phase change

Nepheline g.c. White, opaque the Weibull modulus has also been observed in lithium disilicate glass-ceramics (Fischer et al., 2008).

Tagantsev (1999) has been the first to describe an interesting mechanism in the case of IOX in a lithium metasilicate glass-ceramic: the replacement of lithium ions by sodium ions is associated with an amorphization of the glass-ceramic in the layer undergoing IOX.

Such an amorphization has also been observed by Laczka et al. in glass-ceramics containing both lithium disilicate and lithium aluminosilicate phases. The IOX induced amorphization was found to occur in both crystalline phases (Laczka et al., 2015).

Another phenomenon has been evidenced in nepheline glass-ceramics (Duke et al., 1967; Ponsot et al., 2014): the IOX $\left(\mathrm{K}^{+}\right.$for $\left.\mathrm{Na}^{+}\right)$leads to formation of kalsilite at the surface that leads to a very significant increase of the modulus of rupture.

\section{MATERIALS AND METHODS}

The glasses with the compositions indicated in Table 2 have been melted in platinum crucibles at temperature in the $1600-1650^{\circ} \mathrm{C}$ range. Batches in the range of $1000-2500 \mathrm{~g}$ were used. After melting and fining, the glasses were poured and annealed.

Pieces were cut for the crystallization treatment. The thermal treatments used are reported in Table 2. The crystalline phases were determined by X-ray diffraction (XRD).

Then the samples were ion-exchanged in molten baths. The compositions of the baths as well as the temperature and length of the treatments are summarized on Table 2.

$\mathrm{X}$-ray diffraction was used to determine the effect of IOX on microstructure. A Bragg-Brentano $\theta / 2 \theta$ configuration with a $\mathrm{Cu} \mathrm{K} \alpha_{1}$ radiation was used. Patterns were measured on samples surface before and after IOX. Rietveld analysis was performed (Rodriguez-Carvajal, 1993). The X-Ray penetration depth is roughly $100 \mu \mathrm{m}$ in this configuration. For ionexchanged samples a gradient of crystallization is observed on this thickness and, consequently, the obtained data (e.g., the average size of the crystals or the cell parameters) are mean values.

Grazing Incidence Angle Diffraction (GIAD) was also performed in one case to quantify the microstructure evolution after ionic exchange as a function of thickness.

Grazing Incidence Angle Diffraction measurements at several fixed incident angles $\alpha$ were performed. The fixed incident angles are $1.5,7.5$, and $15^{\circ}$ corresponding, respectively, to depths of $\sim 2,10$, and $20 \mu \mathrm{m}$. Then each depth pattern was quantified by Rietveld refinement.

The mechanical performance of the glass-ceramics was measured by a ring on ring test. This test evaluates the biaxial flexure strength. In some cases, measurements have also been made after abrasion. Abrasion was performed with silicon carbide (grain size $70 \mu \mathrm{m}$ ) during $5 \mathrm{~s}$ at a pressure of $0.10 \mathrm{MPa}$ (except if something else is specified). This last test was used to quantify retained mechanical performance after having imposed a given flaw population. The size of the samples is indicated on Table 2. Ten to 30 optically polished samples were used for each test. 
TABLE 2 | Compositions ( $\mathrm{mol} \%$ ) of the glass-ceramics and experimental conditions.

\begin{tabular}{|c|c|c|c|c|c|c|}
\hline \multirow{2}{*}{$\begin{array}{l}\text { Main crystalline phase } \\
\text { Composition }\end{array}$} & \multicolumn{2}{|c|}{$\begin{array}{l}\mathrm{MgO}-\mathrm{TiO}_{2}-\mathrm{Fe}_{2} \mathrm{O}_{3} \\
\text { with } \mathrm{\epsilon}-\mathrm{Fe}_{2} \mathrm{O}_{3} \text { structure }\end{array}$} & \multirow[t]{2}{*}{$\begin{array}{l}\text { Spodumene } \\
\text { solid solution }\end{array}$} & \multirow[t]{2}{*}{$\begin{array}{l}\text { Li-rich } \beta \text {-quartz } \\
\text { solid solution }\end{array}$} & \multirow[t]{2}{*}{$\begin{array}{l}\text { Mg-rich } \beta \text {-quartz } \\
\text { solid solution }\end{array}$} & \multirow[t]{2}{*}{ Nepheline } \\
\hline & GC1 & GC2 & & & & \\
\hline $\mathrm{SiO}_{2}$ & 63.82 & 63.94 & 69 & 72.8 & 71 & 55 \\
\hline $\mathrm{Al}_{2} \mathrm{O}_{3}$ & 13.89 & 13.6 & 13 & 12.6 & 13 & 20 \\
\hline $\mathrm{B}_{2} \mathrm{O}_{3}$ & 5.1 & 5.18 & & & & \\
\hline $\mathrm{Li}_{2} \mathrm{O}$ & & & 8 & 8.2 & 4 & \\
\hline $\mathrm{Na}_{2} \mathrm{O}$ & 13.76 & 13.66 & & 2.6 & 0.5 & \\
\hline $\mathrm{K}_{2} \mathrm{O}$ & & & & & & 13 \\
\hline $\mathrm{MgO}$ & 1.74 & 1.75 & & & 9 & 5 \\
\hline $\mathrm{MgO}+\mathrm{ZnO}$ & & & 4 & & & \\
\hline $\mathrm{TiO}_{2}$ & 0.98 & 0.99 & 3.6 & 2.1 & & \\
\hline $\mathrm{ZrO}_{2}$ & & & & 0.9 & 2.5 & 7 \\
\hline $\mathrm{Fe}_{2} \mathrm{O}_{3}$ & 0.56 & 0.71 & & & & \\
\hline Other & & & 2.4 & 0.8 & & \\
\hline \multicolumn{7}{|l|}{ Crystallization heat treatment: } \\
\hline - Nucleation $\left({ }^{\circ} \mathrm{C}-\mathrm{h}\right)$ & & & $780-2$ & $\begin{array}{c}\text { Ramp from } 650 \text { to } \\
820-0.66\end{array}$ & $820-4$ & $850-2$ \\
\hline - Growth $\left({ }^{\circ} \mathrm{C}-\mathrm{h}\right)$ & & $50-4$ & $975-4$ & $900-0.25$ & $875-4$ & $1050-2$ \\
\hline \multicolumn{7}{|l|}{ Typical IOX conditions (1): } \\
\hline - Bath & $\mathrm{KNO}_{3}$ & $\mathrm{KNO}_{3}$ & $\mathrm{NaNO}_{3}$ & $\mathrm{KCl} / \mathrm{K}_{2} \mathrm{SO}_{4}{ }^{\mathrm{a}}$ & $\mathrm{Li}_{2} \mathrm{SO}_{4} / \mathrm{K}_{2} \mathrm{SO}_{4}{ }^{\mathrm{a}}$ & $\mathrm{KNO}_{3}$ \\
\hline - Temperature $\left({ }^{\circ} \mathrm{C}\right)$ & 420 & 430 & Around 400 & $700-725$ & 710-800 & 450 \\
\hline - Time (h) & 6.5 & 8 & $2-4$ & $4-8$ & $4-16$ & $2-48$ \\
\hline \multicolumn{7}{|l|}{ Typical IOX conditions (2): } \\
\hline - Bath & & & & & & $\mathrm{KCl} / \mathrm{K}_{2} \mathrm{SO}_{4}{ }^{\mathrm{a}}$ \\
\hline - Temperature $\left({ }^{\circ} \mathrm{C}\right)$ & & & & & & 700 \\
\hline - Time (h) & & & & & & $0.5-16$ \\
\hline Sample size for ring on ring test & \multicolumn{3}{|c|}{ 50-mm square, 0.8-mm thick } & \multicolumn{2}{|c|}{ 32-mm diameter, 2.1-mm thick } & $\begin{array}{l}\text { 50-mm square, } \\
\text { 0.8-mm thick }\end{array}$ \\
\hline
\end{tabular}

alOX bath compositions: $\mathrm{KCl} 54$ wt\%/K $\mathrm{SSO}_{4} 48 w t \%$ and $\mathrm{Li}_{2} \mathrm{SO}_{4} 90 \mathrm{wt} \% / \mathrm{K}_{2} \mathrm{SO}_{4} 10 w t \%$.

The reported results are the load to failure distribution because in most cases the strength of the ion-exchanged samples was so high that bending displacement was large enough to make the membrane stresses non-negligible. Therefore, conventional failure stress calculations would overestimate the material stress at failure. The Weibull shape and scale parameters corresponding to failure load are also reported. The scale parameter corresponds to $63.2 \%$ of failure probability.

\section{RESULTS}

\section{lon-Exchange in the Residual Glass}

The example given here has been obtained developing a glassceramic suitable as backs of portable electronic devices (Dejneka et al., 2014).

As compared to metals, this glass-ceramic has the advantage to be transparent to microwave and radio frequency radiation. As compared to glasses, it allows to obtain a black aspect and to be opaque enough to hide the interior of the devices. Other requirements were a high mechanical resistance and, to limit cost, the need to have a precursor glass that can be formed by methods, such as fusion draw. This last requirement allows obtaining thin sheets with pristine surfaces (therefore, no further polishing is needed to obtain products).

However, this last requirement is not met by most of the glass-ceramics as they present generally relatively low viscosity at the liquidus (typically lower than $2 \mathrm{kPa}$ s). If such a liquidus is suitable to form articles by pressing or rolling, it prevents the use of forming methods, such as fusion draw for which at least $20 \mathrm{kPa} s$ are required.

To obtain a product meeting all these requirements, sodium aluminosilicate glasses displaying high viscosity at the liquidus were used (Table 2). With such glasses, it is known that exchange of sodium ions by potassium is easily obtained and can lead to outstanding mechanical strength. These glasses have been doped with about $1 \% \mathrm{TiO}_{2}$ and $\mathrm{Fe}_{2} \mathrm{O}_{3}$. After thermal treatment, crystallization of $\mathrm{MgO}-\mathrm{TiO}_{2}-\mathrm{Fe}_{2} \mathrm{O}_{3}$ with a $\epsilon-\mathrm{Fe}_{2} \mathrm{O}_{3}$ structure takes place. The mean size of the crystals is smaller than about $20 \mathrm{~nm}$ (Figure 1). This glass-ceramic has several advantages:

- It displays a black color not easy to achieve in a glass; this color is due to $\mathrm{Fe}^{2+}-\mathrm{Ti}^{4+}$ charge transfer absorption in the crystals.

- As their levels are low, $\mathrm{TiO}_{2}$ and $\mathrm{Fe}_{2} \mathrm{O}_{3}$ do not change the viscosity at the liquidus and the precursor glass stays fusion formable.

- As the level of crystallinity is low, the composition of the residual glass is close to the composition of the base glass and is favorable to an IOX leading to mechanical properties close to those of the undoped glass.

Figure 2 displays the results of the mechanical test performed on two of these materials in comparison with a Corning ${ }^{\circledR}$ Gorilla $^{\circledR}$ 
Glass (CGG). In the three cases, IOX increases very significantly the load to failure: from scale parameters of 380-460 $\mathrm{N}$ to values higher than $2300 \mathrm{~N}$.

The slopes of the failure probability line are also significantly steeper: the Weibull shape factors that are in the 2.9-4.6 range

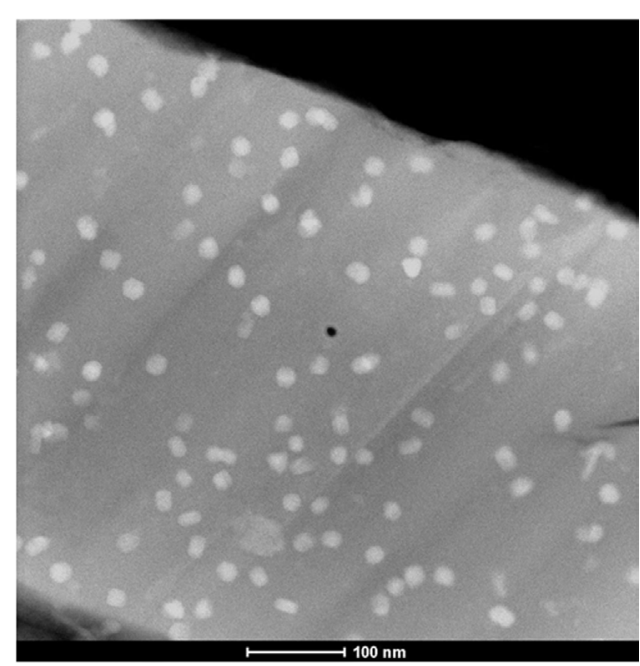

FIGURE 1 | TEM micrograph of the low crystallinity $\mathrm{MgO}-\mathrm{TiO}_{2}-\mathrm{Fe}_{2} \mathrm{O}_{3}$ glass-ceramic. (Composition GC2 - Table 1- cerammed at $750^{\circ} \mathrm{C}$ for $4 \mathrm{~h}$ ). before IOX increase to values in the 15-19 range after IOX. The two glass-ceramics have properties at least as good as CGG.

\section{Ion-Exchange Leading to Surface Amorphization: Li-Rich $\beta$-Quartz Solid Solution Glass-Ceramics}

Glass-ceramics based on crystallization of $\beta$-quartz solid solution have been discovered in the 60s. The general chemical formula of the $\beta$-quartz solid solution is $\mathrm{Li}_{2-2(\mathrm{x}+\mathrm{y})} \mathrm{Mg}_{\mathrm{x}} \mathrm{Zn}_{\mathrm{y}} \mathrm{O} \cdot \mathrm{Al}_{2} \mathrm{O}_{3} \cdot \mathrm{nSiO}_{2}$ (with $n=2-10$ ) where $\mathrm{Al}^{3+}$ ions replace $\mathrm{Si}^{4+}$ in tetrahedral sites and local electrical neutrality is ensured by the incorporation of small ions, such as $\mathrm{Li}^{+}, \mathrm{Mg}^{2+}$ or $\mathrm{Zn} 2+$, into the channels of the structure. Nucleation is ensured by the addition to the batch of $\mathrm{TiO}_{2}$ and/or $\mathrm{ZrO}_{2}$ (a few mol\%).

It is possible in this system to obtain highly crystalline transparent material by controlling the size of the crystallites (smaller than about $50 \mathrm{~nm}$ ). An example of microstructure as observed by SEM is given in Figure 3.

The success of these glass-ceramics relies on the ability of some of these compositions (containing mainly lithium as compensator ion) to obtain materials that combine transparency, zero or very low thermal expansion coefficient, and ability to withstand temperatures of at least $700^{\circ} \mathrm{C}$ during several thousand hours without deformation or substantial modifications of the properties. They have found a wide range of applications ranging from telescope mirrors to ferrules for optical connectors or to

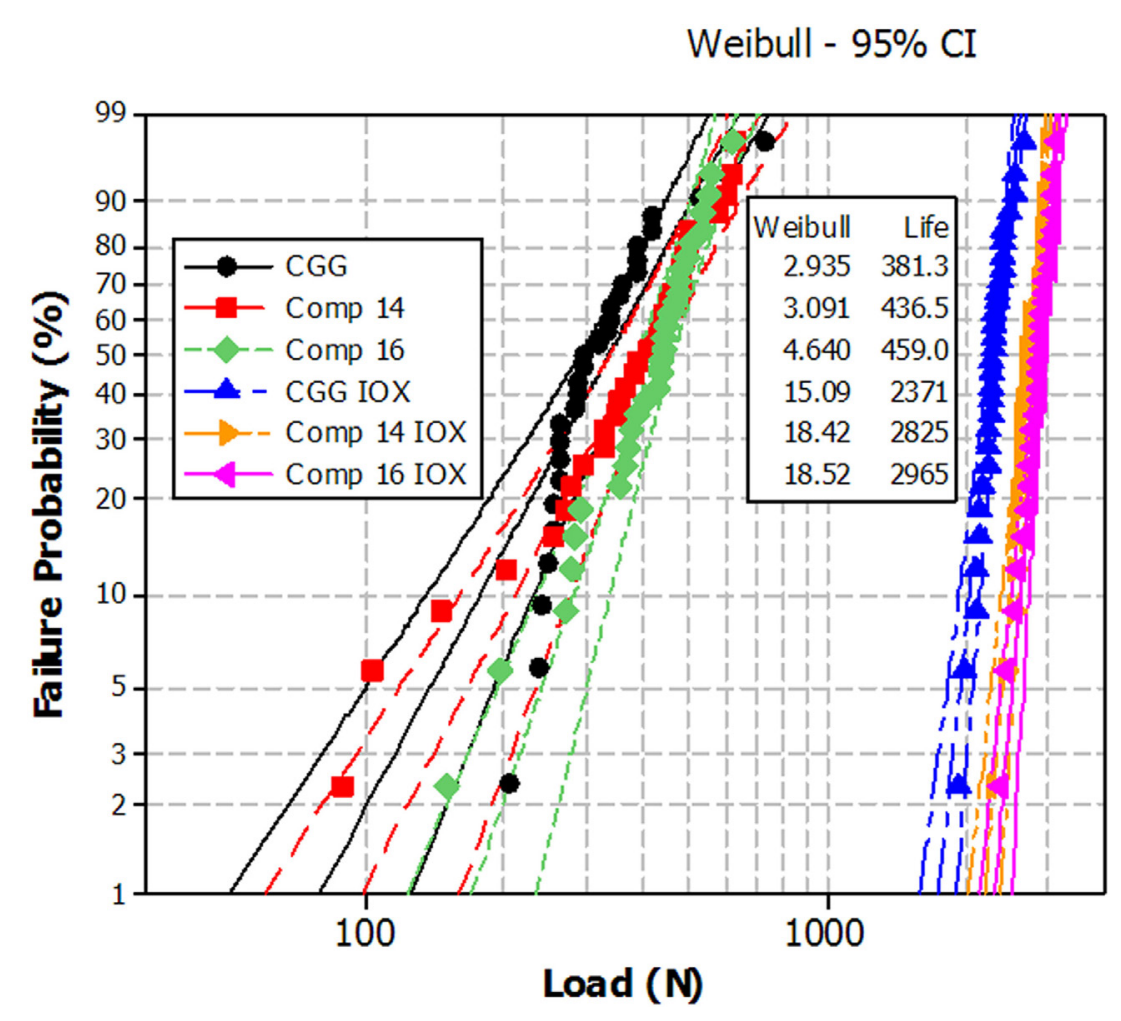

FIGURE 2 Ring on ring biaxial flexure load to failure of low crystallinity $\mathrm{MgO}^{-} \mathrm{TiO}_{2}-\mathrm{Fe}_{2} \mathrm{O}_{3}$ glass-ceramics (cerammed at $700^{\circ} \mathrm{C}$ for $4 \mathrm{~h}$ compared to CGG before and after ion-exchange). The dashed lines indicate the $95 \%$ confidence intervals. For the three ion-exchanged materials, compression is present on a layer around $40-\mu \mathrm{m}$ thick. 

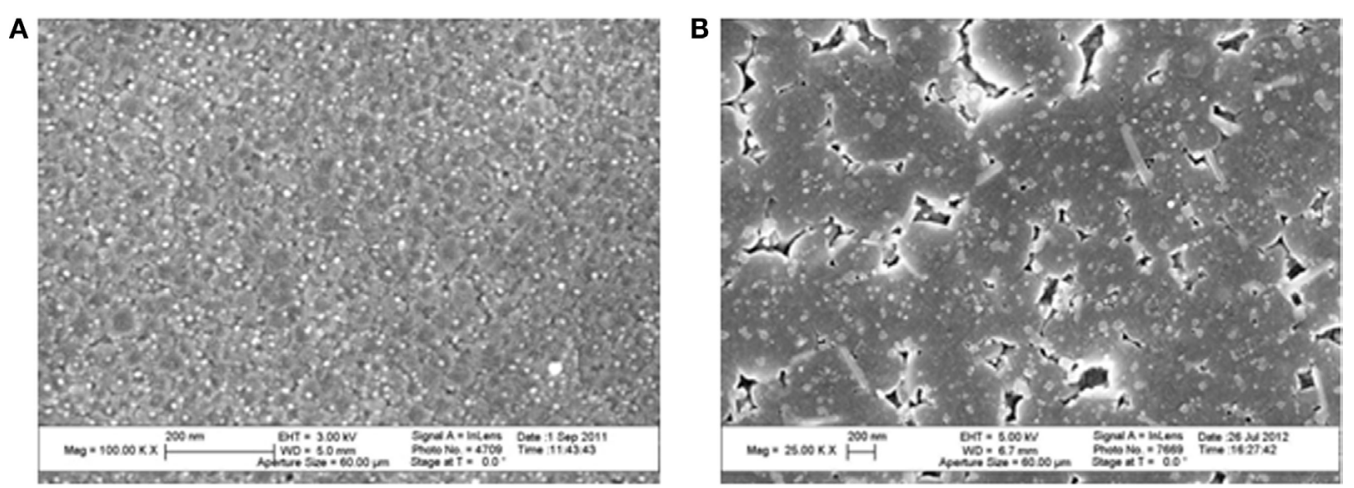

FIGURE 3 | Microstructures of glass-ceramics observed by SEM. They have been revealed by chemical etching. Source: Anne Crochet (Corning SAS). (A) Li-rich $\beta$-quartz solid solution glass-ceramic $\beta$-quartz crystals appear in gray and have a size around $30 \mathrm{~nm}$. TiZrO ${ }_{4} \mathrm{Crystals}$ appear in white and have a size of a few nanometers. (B) $\beta$-spodumene solid solution glass-ceramic. The pores correspond to the residual glass that has been etched. The bigger blocks are spodumene crystals, the small white dots with a size around $30 \mathrm{~nm}$ are spinel and the elongated crystals are rutile.

consumer products, such as cooktops, cookware, or fire-resistant windows.

As already observed (Beall et al., 1967), it has not been possible to obtain an increase of mechanical strength replacing lithium ions by sodium but exchange of lithium by potassium is efficient: in this case IOX has been performed during $4-16 \mathrm{~h}$ in the $700-725^{\circ} \mathrm{C}$ range in a $\mathrm{KCl} / \mathrm{K}_{2} \mathrm{SO}_{4}$ bath. The measurement of the potassium profile shows that the depth of penetration of this ion is in the $20-60 \mu \mathrm{m}$ range according to the time and temperature of exchange. Figure 4 displays such profiles after IOXs of, respectively, 4 and $8 \mathrm{~h}$ at $700^{\circ} \mathrm{C}$. The depth of diffusion of potassium is around $20 \mu \mathrm{m}$ after $4 \mathrm{~h}$ and $35 \mu \mathrm{m}$ after $8 \mathrm{~h}$. This exchange is associated with a significant increase of mechanical strength: Weibull scale parameter of 4092 and $1953 \mathrm{~N}$ have been obtained after, respectively, 4 and $8 \mathrm{~h}$, as compared to $820 \mathrm{~N}$ for the non-ion-exchanged glass-ceramic. However, it is observed that increasing the IOX time from 4 to $8 \mathrm{~h}$ reduces very significantly the mechanical strength dividing the scale parameter by 2 .

Surface XRD (BB and GIAD) performed before and after an IOX of $4 \mathrm{~h}$ at $700^{\circ} \mathrm{C}$ evidence a strong microstructure modification (Figure 5): before IOX, the main crystalline phase is $\beta$-quartz solid solution with minor amount of the $\mathrm{TiZrO}_{4}$ nucleating phase. After IOX, the crystalline phases are the same but an increase of the amorphous content is observed on the patterns (Figure 5). Rietveld analysis shows that the average size of the $\beta$-quartz solid solution crystals has significantly decreased (roughly divided by two). These observations strongly suggest that the IOX is associated with a surface amorphization. The GIAD measurements confirm these observations: after IOX, a strong decrease of the amount of the $\beta$-quartz phase is observed, this decrease being more important closer to the surface.

\section{Ion-Exchange in the Crystalline Phase Ion-Exchange in Mg-Rich $\beta$-Quartz Solid Solution Glass-Ceramics}

We focus now on $\beta$-quartz solid solution glass-ceramics containing mainly magnesium to charge balance aluminum and with

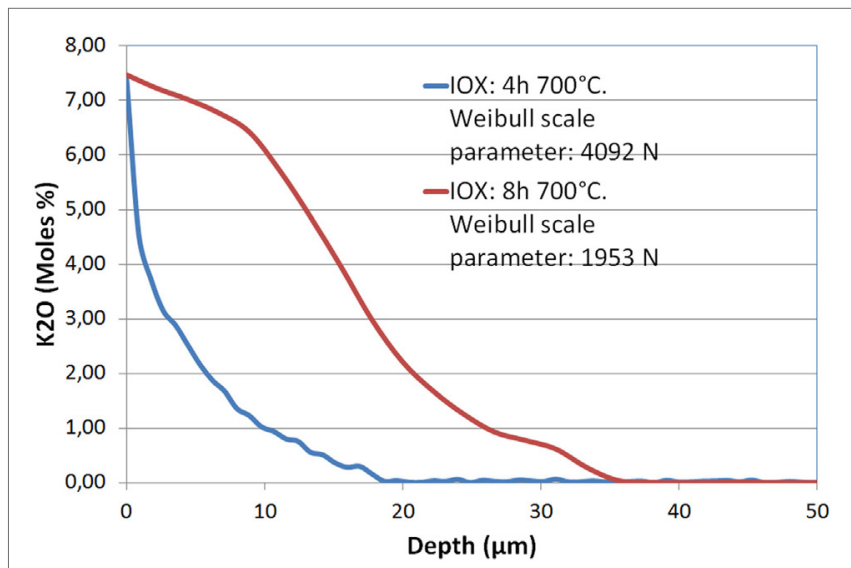

FIGURE 4 | Diffusion profile of $\mathrm{K}_{2} \mathrm{O}$ in a Li-rich $\beta$-quartz solid solution glass-ceramic after an ion-exchange of 4 and $8 \mathrm{~h}$ at $700^{\circ} \mathrm{C}$ in a $\mathrm{KCl} /$ $\mathbf{K}_{2} \mathbf{S O}_{4}$ bath. The Weibull scale parameters reported in the legend show that the longer IOX is associated with a significant strength decrease.

composition given in Table 2. The glass-ceramic is transparent (Table 1). Because of the use of $\mathrm{ZrO}_{2}$ alone as nucleating agent, it displays a very high transmission without the residual yellow color generally brought by the addition of $\mathrm{TiO}_{2}$ (Table 2). IOX was performed in a $\mathrm{Li}_{2} \mathrm{SO}_{4} / \mathrm{K}_{2} \mathrm{SO}_{4}$ bath at temperatures in the range of $710-800^{\circ} \mathrm{C}$, during $4-16 \mathrm{~h} . \mathrm{K}_{2} \mathrm{SO}_{4}$ is added to lower the melting temperature. In these conditions, diffusion of lithium ions takes place to a depth of $40-200 \mu \mathrm{m}$.

After an IOX of $4 \mathrm{~h}$ at $710^{\circ} \mathrm{C}$, surface XRD (BB) reveals an increase of the cell parameters of the $\beta$-quartz solid solution, suggesting that $2 \mathrm{Li}^{+}$ions replace $\mathrm{Mg}^{2+}$ in the structure (Figure 6).

Ion-exchange is associated with a very significant increase of the flexural strength as indicated in Figures 7 and 8 . Figure 7 gives the results of the mechanical test performed on glass-ceramics before and after an IOX of $16 \mathrm{~h}$ at $725^{\circ} \mathrm{C}$ and in this last case before and after abrasion. It is observed that abrasion decreases only very little the load to failure. 


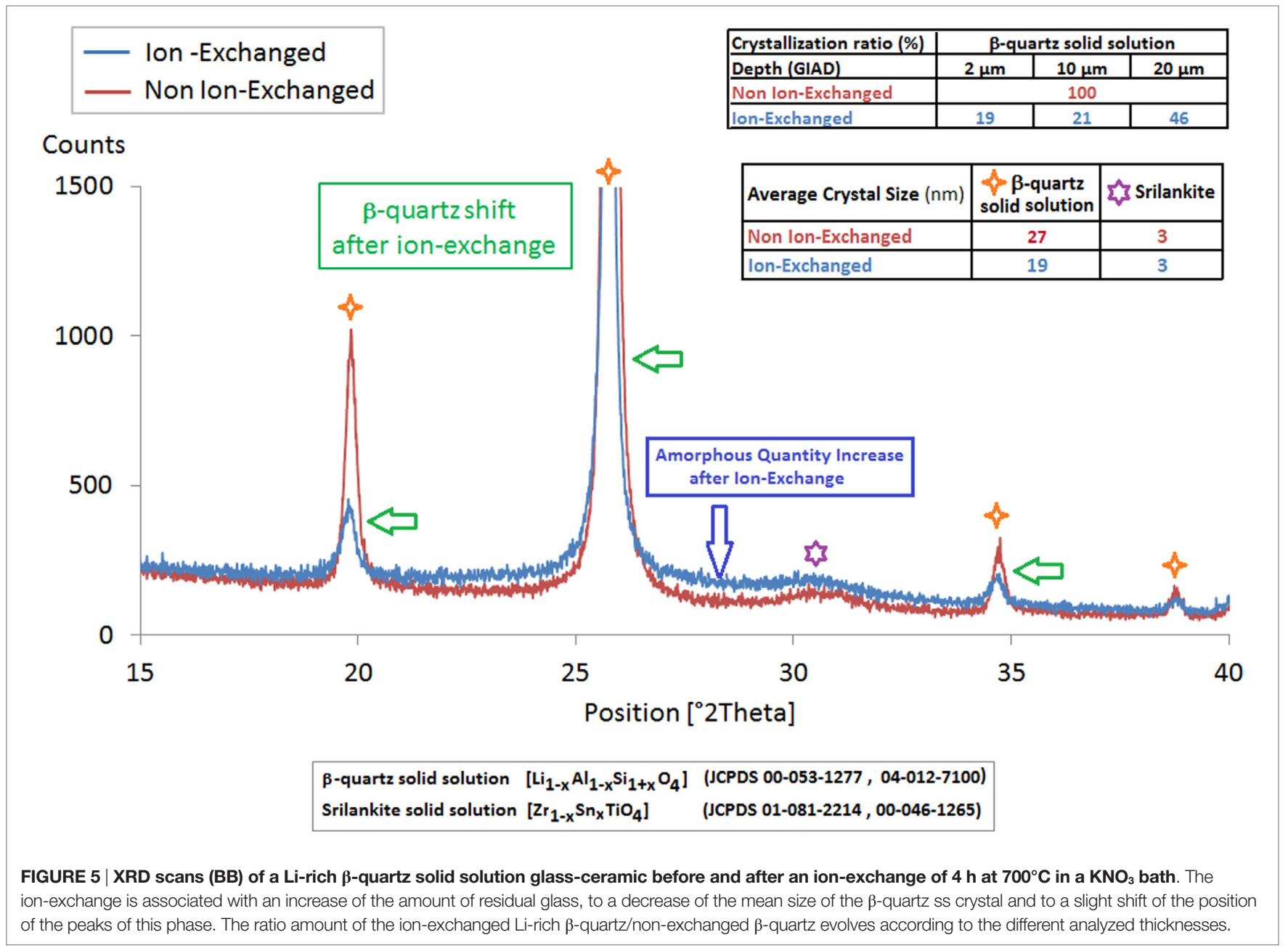

Figure 8 gives the Weibull scale factor and the thickness of the surface layer in compression (DOL) for different IOX treatments. The mechanical strength attains a maximum at $725^{\circ} \mathrm{C}$, then decreases for higher temperature of the bath.

This decrease seems associated with considerable potassium diffusion in the glass-ceramic above $750^{\circ} \mathrm{C}$. This potassium diffusion inhibits the diffusion of magnesium. Diffusion profiles of magnesium and potassium after IOXs of respectively $4 \mathrm{~h}$ at 750 and $775^{\circ} \mathrm{C}$ illustrate this effect (Figure 9).

\section{Ion-Exchange in Spodumene Glass-Ceramic}

Spodumene glass-ceramics have been known for a very long time. They have been used and are still used to produce cookware materials and cooktops thanks to their low thermal expansion [coefficient of thermal expansion (CTE) around $10-20 \times 10^{7} \mathrm{~K}^{-1}-25-700^{\circ} \mathrm{C}$ ].

The crystalline phase is a solid solution with formula $\mathrm{Li}_{2} \mathrm{O}-$ $\mathrm{Al}_{2} \mathrm{O}_{3}-\mathrm{nSiO}_{2}$ with $n=2-8$. The material studied here has been nucleated through the addition of a few wt.\% of $\mathrm{TiO}_{2}$. Figure 3B displays a SEM micrograph of this material. The spodumene crystals have a mean size of about $1 \mu \mathrm{m}$. Small amounts of rutile and spinels are also visible. The amount of residual glass is estimated to be around $10 \%$ wt.
Ion-exchange in a sodium nitrate bath leads to incorporation of sodium into the glass-ceramic. After exchanging for a few hours around $400^{\circ} \mathrm{C}$ in a sodium nitrate bath, the sodium ions diffuse up to a depth of around $100 \mu \mathrm{m}$ as observed by microprobe technique (Figure 10). It is believed that sodium replaces lithium that cannot be analyzed by this technique. The concentration of the other elements is constant through the thickness. This IOX is proposed to take place in the crystals. A proof of that is given by the comparison of XRD patterns obtained, respectively, before and after IOX and that shows a very significant increase of the $\beta$-spodumene cell parameters, which is in good agreement with the replacement of Li by sodium in the crystals (Figure 11).

The result of the ring on ring test is indicated on Figure 12. The Weibull scale parameters are, respectively, 1341 and $780 \mathrm{~N}$ before and after abrasion.

\section{Ion-Exchange Leading to a Crystalline Phase Modification}

Nepheline is a stuffed derivative of tridymite with formula $(\mathrm{Na}, \mathrm{K})$ $\mathrm{AlSiO}_{4}$. A white opaque glass-ceramic containing nepheline as main crystalline phase can be obtained using $\mathrm{TiO}_{2}$ as nucleating 


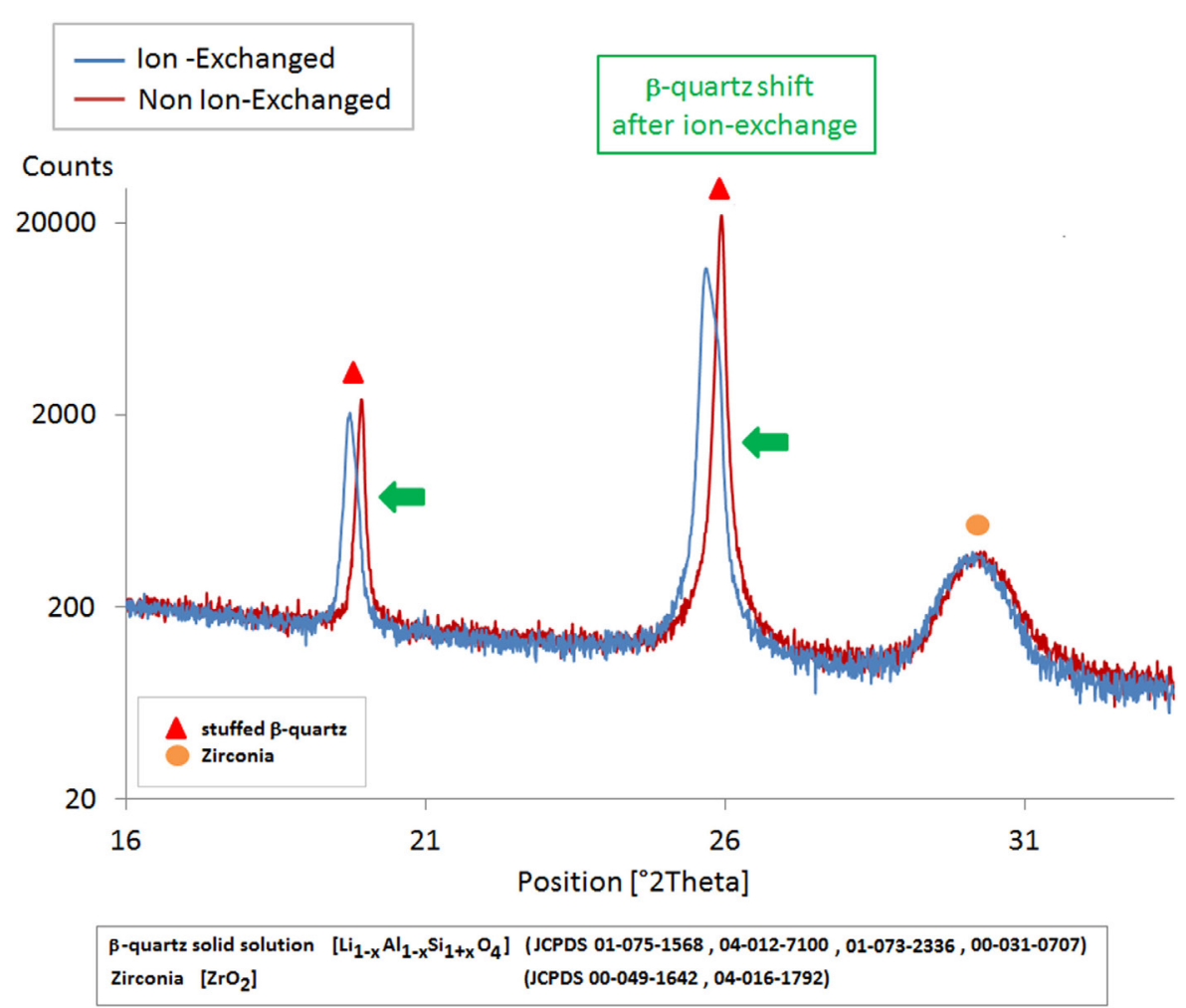

FIGURE 6 | XRD scans (BB) of a Mg-rich $\beta$-quartz solid solution glass-ceramic before and after an ion-exchange of $4 \mathrm{~h}$ at $710^{\circ} \mathrm{C}$ in a $\mathrm{Li}_{2} \mathrm{SO}_{4} / \mathrm{K}_{2} \mathrm{SO}_{4}$ bath. The ion-exchange is associated with a shift of the position of the peaks of the $\beta$-quartz phase and an increase of the cell parameters. At the difference of what was observed with Li-rich $\beta$-quartz solid solution (Figure 5), there is no change in the amount of residual glass here.

agent. Starting from a glass rich in sodium, it has been observed that sodium can be exchanged with potassium or in a potassium nitrate bath at $450^{\circ} \mathrm{C}$ or in a $\mathrm{KNO}_{3} / \mathrm{KCl}$ bath at $700^{\circ} \mathrm{C}$.

The diffusion of potassium and sodium obtained after $0.5 \mathrm{~h}$ at $700^{\circ} \mathrm{C}$ is represented on Figure 10: a diffusion of potassium on about $100 \mu \mathrm{m}$ is observed. However, there is a strong accumulation of potassium in a $10-\mu \mathrm{m}$ thick layer near the surface. In this layer, XRD (GIAD) has shown that nepheline $\left[\mathrm{Na}_{7.11}\left(\mathrm{Al}_{7.2} \mathrm{Si}_{8.8} \mathrm{O}_{32}\right)\right]$ (JCPDS 01-079-0991) has transformed to kalsilite [ $\left.\mathrm{KAlSiO}_{4}\right]$ (JCPDS 00-011-0579) (Figure 13).

The formation of kalsilite results in a very high load to failure (Figure 12) higher than for the ion-exchanged $\beta$-spodumene glass-ceramic described in 3.3.2. However, after abrasion results are inverted: the nepheline glass-ceramic displays a lower strength than the $\beta$-spodumene one.

\section{DISCUSSION}

The black fusion formable glass-ceramics in which IOX takes place in the residual glass combine the interesting properties of both the crystals and the residual glass: the crystals give to the material its black opaque aspect but are in small enough amount to keep a high viscosity at the liquidus compatible with forming by fusion draw and not to prevent the IOX process that takes place in the residual glass. The residual glass has a composition close to
CGG and leads to mechanical properties at least similar to those of the ion-exchanged CGG.

In the case of IOX involving ions in a crystalline phase, more diverse and complex mechanisms are observed:

$\beta$-spodumene glass-ceramics are easy to strengthen by IOX: the sodium for lithium exchange takes place at relatively low temperature (around $400^{\circ} \mathrm{C}$ ) and short times (a few hours). Significant diffusion (around $100 \mu \mathrm{m}$ ) is easily achieved. The surface compression and the improvement of the mechanical strength are due to the volume increase of the crystals.

Ion-exchanges are much more difficult to achieve with $\beta$-quartz solid solution:

- Replacement of lithium by another alkali in the crystal structure does not appear possible. Exchange of lithium by potassium takes place but at high temperatures $\left(700-725^{\circ} \mathrm{C}\right)$ and as potassium cannot be incorporated to the structure, it is associated with a destruction of the crystals. As described earlier, such a phenomenon has already been observed in lithium metasilicate glass-ceramics exchanging sodium for lithium (Tagantsev, 1999) and in glass-ceramics containing both lithium disilicate and lithium aluminosilicate phases (Laczka et al., 2015). The amorphization leads to a volume increase (the glass being less dense than the crystals), which results in compressive stresses. However, amorphization is 
also associated with an increase of the coefficient of thermal expansion (CTE) and stress relaxation, which limit strengthening. This competition between compressive stress from the volume change and the higher CTE in the amorphous phase is probably what explains the modest increase of mechanical strength after $8 \mathrm{~h}$ of IOX at $725^{\circ} \mathrm{C}$ despite significant potassium diffusion (Figure 4).

- The exchange of magnesium by lithium takes place in the $\beta$-quartz crystals. It should be noted that, as in the previous case, high temperatures are needed to obtain this exchange. The strengthening mechanism is coming from two effects already described in the literature (Beall et al., 1967): the increase of the volume of the crystals (Figure 6) but also the formation of a surface layer with, in contrast to the previous case, a lower CTE than the bulk: the Li-rich $\beta$-quartz solid solution crystals display lower CTE than the Mg-rich crystals (thermal expansions of magnesium containing glass-ceramics in the $\mathrm{SiO}_{2}-\mathrm{MgAl}_{2} \mathrm{O}_{4}$ join range from 30 to $45 \times 10^{-7} \mathrm{~K}^{-1}$ at $50-70 \mathrm{w} \% \mathrm{SiO}_{2}$ while the thermal expansion of the lithium bearing glass-ceramic in the $\mathrm{SiO}_{2}-\mathrm{LiAlSiO}_{4}$ join is slightly negative, about $-5 \times 10^{-7} \mathrm{~K}^{-1}$ ). The combination of these two mechanisms leads to high mechanical performances. The very small effect of abrasion on the load to failure is worth to be noted. Beside that these glass-ceramics display very different physical properties as compared to CGG: namely a much lower CTE $\left(22 \times 10^{-7} \mathrm{~K}^{-1}-25-300^{\circ} \mathrm{C}\right.$ - versus 85$)$ and higher Young modulus (98 versus $65 \mathrm{GPa}$ ) Vickers hardness (900 versus 556) and toughness (0.84 $\mathrm{MPa}^{\mathrm{m}}{ }^{\mathrm{m} / 2}$ versus $0.67-$ measured by chevron notch). Another difference as compared to glass is that because of the very high IOX temperatures

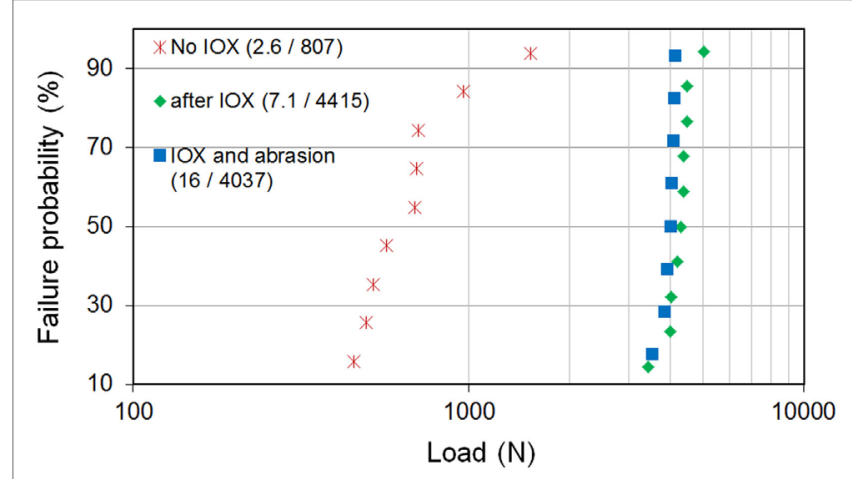

FIGURE 7 | Ring on ring biaxial flexure load to failure of an Mg-rich $\beta$-quartz solid solution glass-ceramic before and after an ionexchange of $16 \mathrm{~h}$ at $725^{\circ} \mathrm{C}$ in $\mathbf{a ~ L i}_{2} \mathrm{SO}_{4} / \mathrm{K}_{2} \mathrm{SO}_{4}$ bath. After ion-exchange, results are given before and after abrasion. Abrasion has been performed with a pressure of $0.17 \mathrm{MPa}$. In the legend, $(X Y)$ are the Weibull shape $(X)$ and scale $(Y)$ parameters.

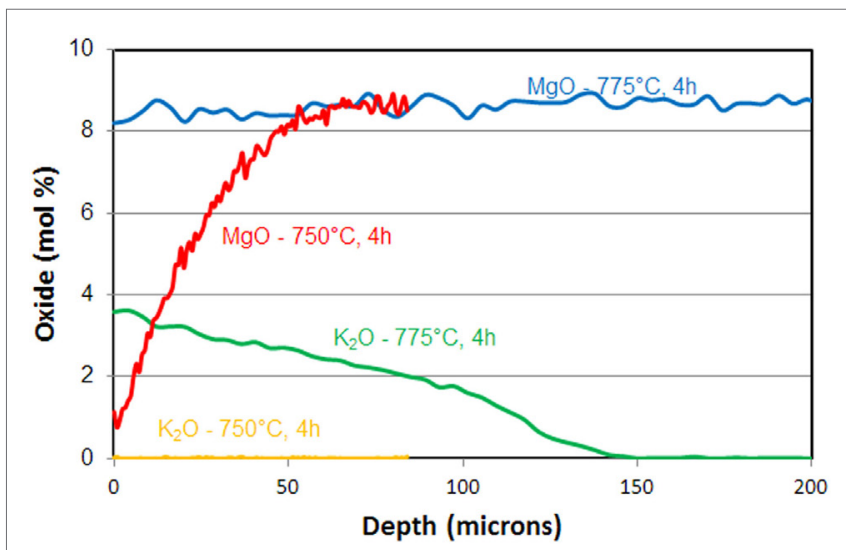

FIGURE 9 | Diffusion profile of $\mathrm{MgO}$ and $\mathrm{K}_{2} \mathrm{O}$ in a $\mathrm{Mg}$-rich $\beta$-quartz solid solution glass-ceramic after ion-exchange of $4 \mathrm{~h}$ in a $\mathrm{Li}_{2} \mathrm{SO}_{4} /$ $\mathrm{K}_{2} \mathrm{SO}_{4}$ bath at 750 and $775^{\circ} \mathrm{C}$.

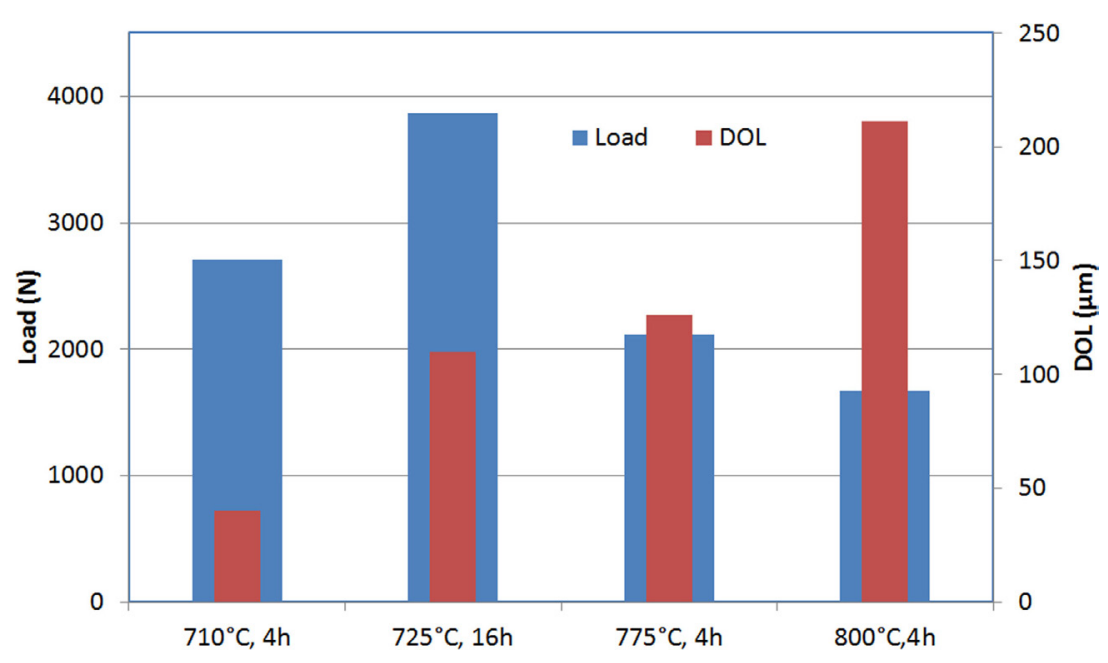

FIGURE 8 | Ring on ring biaxial flexure load to failure of Mg-rich $\beta$-quartz glass-ceramics exchanged in various conditions: the results reported are the Weibull scale factor and the thickness of the surface layer in compression (determined by an optical method). 


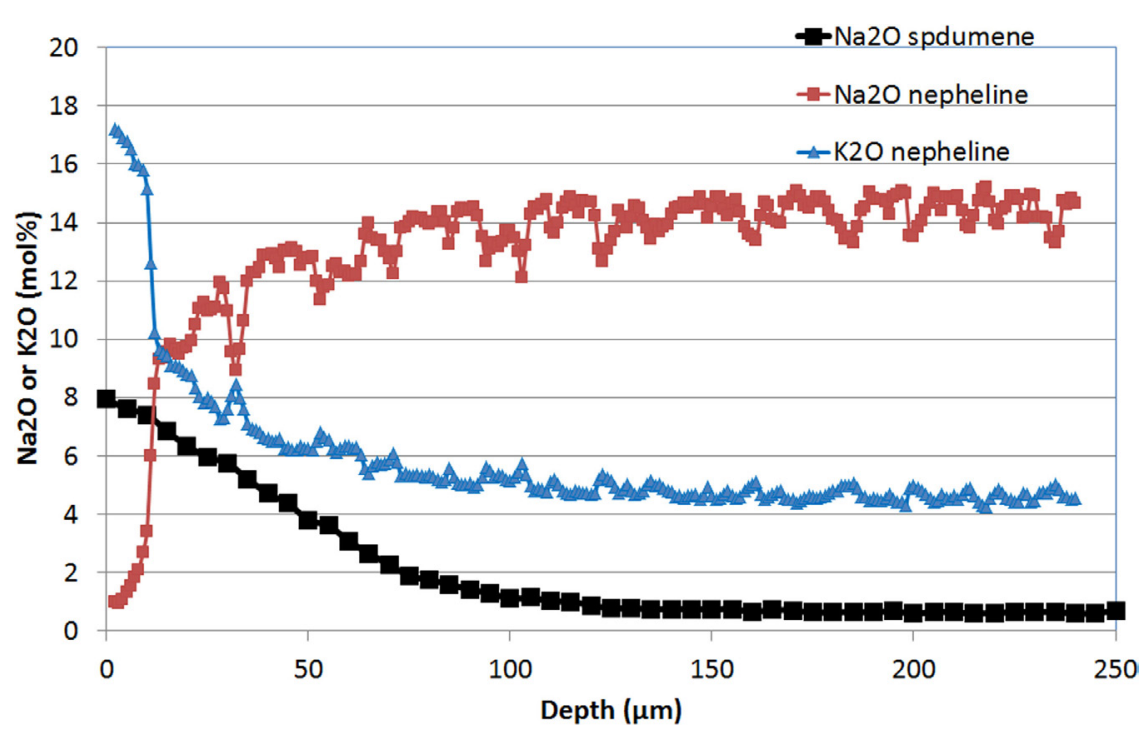

FIGURE 10 Diffusion profile as measured by microprobe (EPMA) of $\mathrm{Na}_{2} \mathrm{O}$ in a $\beta$-spodumene glass-ceramic after an ion-exchange of $2 \mathrm{~h}$ at $430^{\circ} \mathrm{C}$ in a sodium nitrate bath and of $\mathrm{Na}_{2} \mathrm{O}$ and $\mathrm{K}_{2} \mathrm{O}$ in a nepheline glass-ceramic after an ion-exchange of $0.5 \mathrm{~h}$ at $700^{\circ} \mathrm{C}$ in a $\mathrm{KCl} / \mathrm{K}_{2} \mathrm{SO}_{4}$ bath. The concentrations of the other measured elements are constant through the thickness $\left(\mathrm{Li}_{2} \mathrm{O}\right.$ has not been measured).

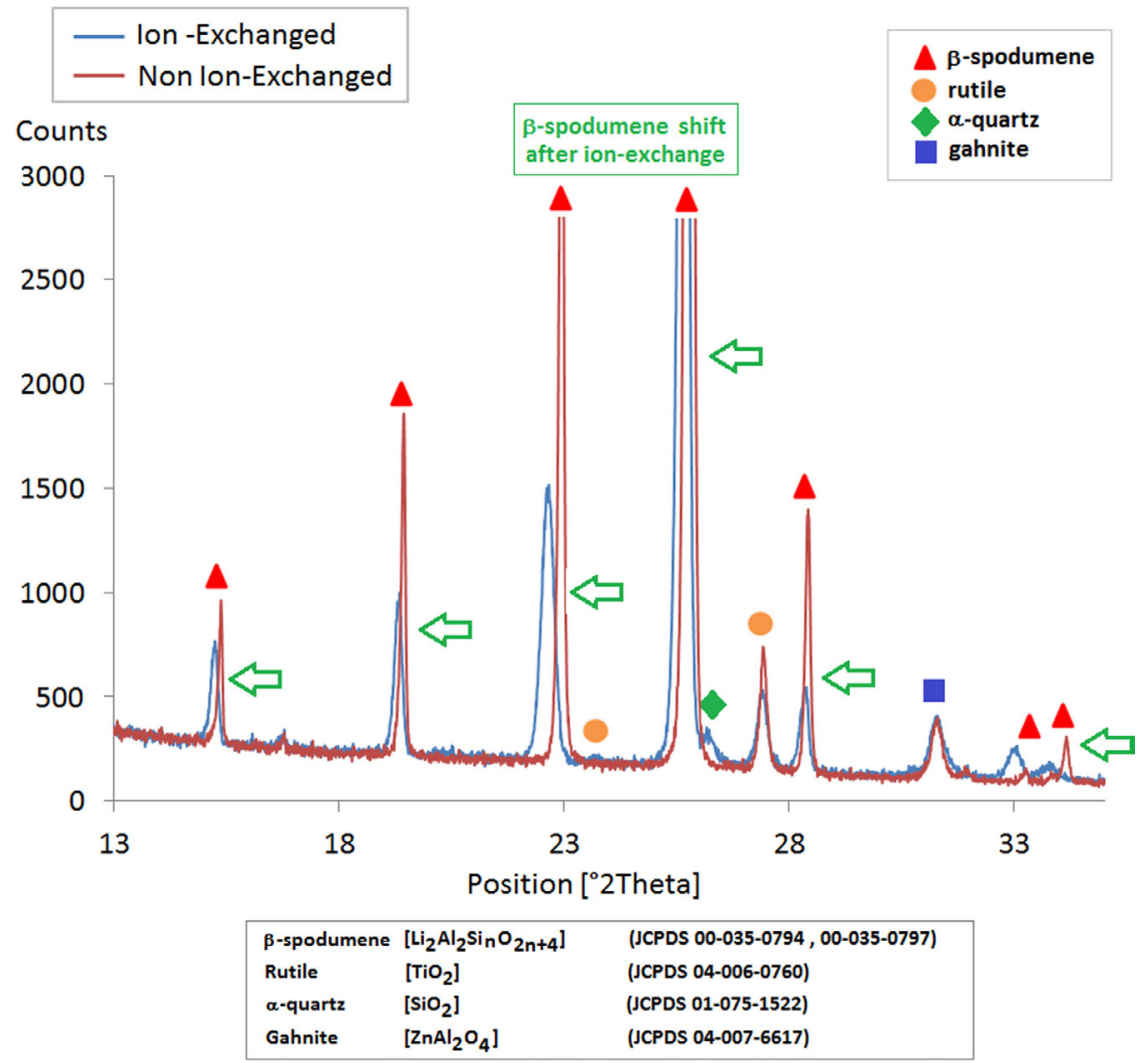

FIGURE 11 | XRD scans of a $\boldsymbol{\beta}$-spodumene glass-ceramic before and after ion-exchange. The peaks related to rutile and gahnite do not shift with ion-exchange, while the other peaks that belong to $\beta$-spodumene shift during ion-exchange toward lower $2 \theta$ values showing an increase of the cell parameters and of the volume of the crystals. 


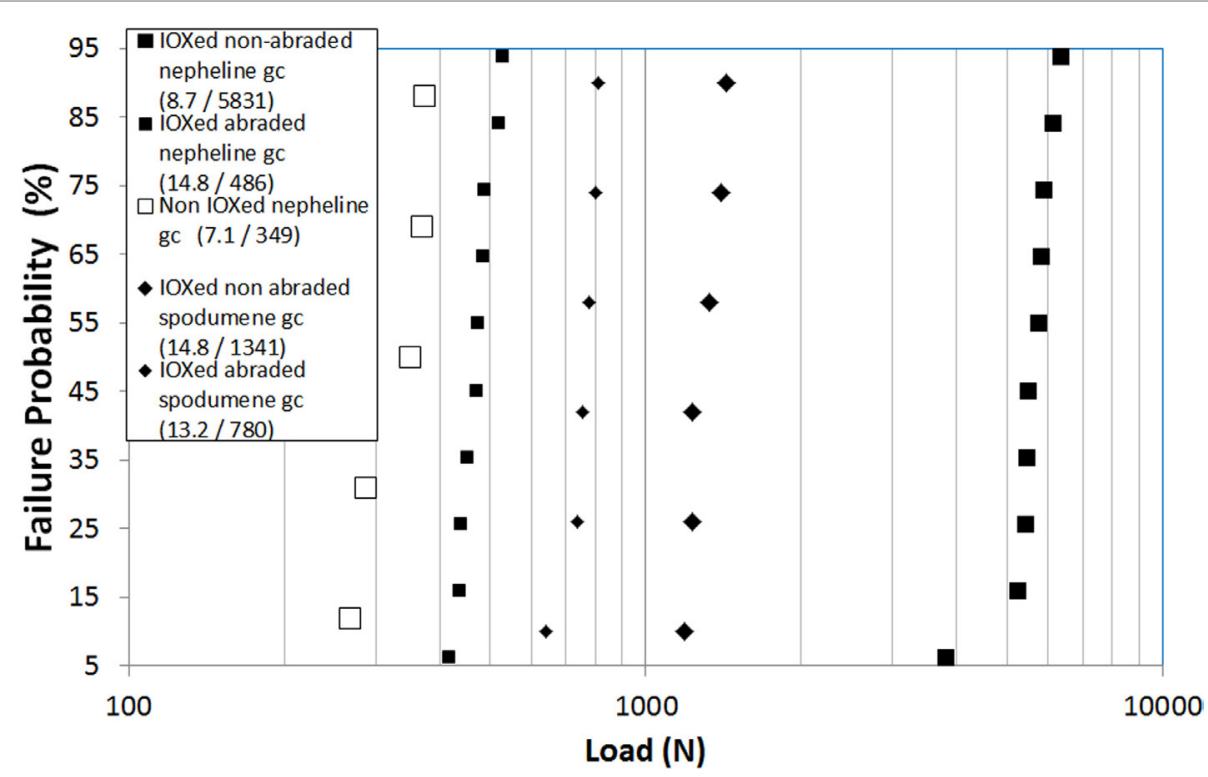

FIGURE 12 | Ring on ring biaxial flexure load to failure of a $\beta$-spodumene glass-ceramic after ion-exchange and of a nepheline glass-ceramic before and after ion-exchange. In both cases, after ion-exchange, results are given before and after abrasion. In the legend, $(X Y)$ are the Weibull shape $(X)$ and scale $(Y)$ parameters. The nepheline glass-ceramic has been exchanged for $6 \mathrm{~h}$ at $450^{\circ} \mathrm{C}$.

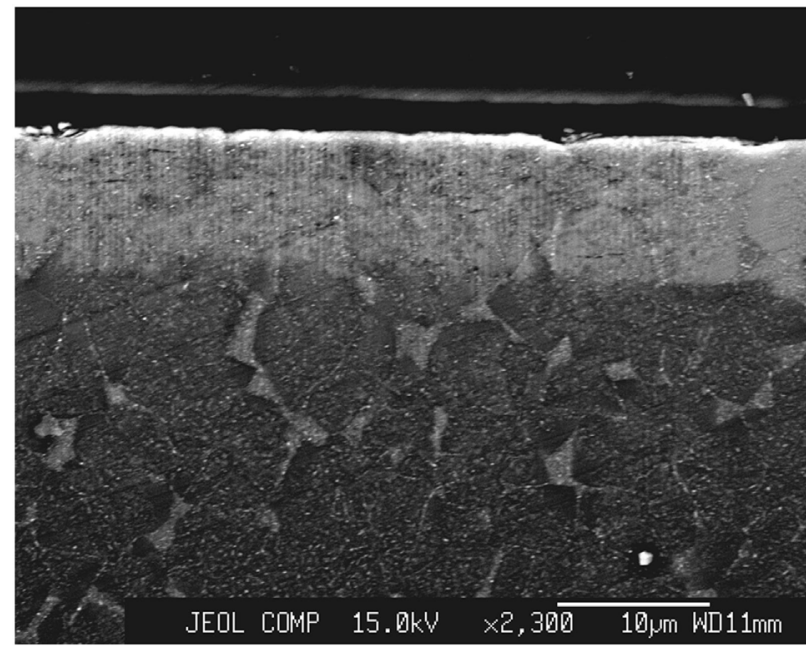

FIGURE 13 | Microstructure of the ion-exchanged zone of a nepheline glass-ceramic observed by SEM (backscattering). The potassium rich zones appear whiter. The 10- $\mu \mathrm{m}$ whiter layer near the surface (top) is crystallized in kalsilite. Under that layer glassy pockets are observed between the nepheline crystals. They are enriched in potassium as compared to the crystals. Ion-exchange conditions: $0.5 \mathrm{~h}$ at $700^{\circ} \mathrm{C}$ in a $\mathrm{KCl} / \mathrm{K}_{2} \mathrm{SO}_{4}$ bath.

relaxation is not observed when these glass-ceramics are used at temperature below $\sim 500^{\circ} \mathrm{C}$ All these specific properties could open to these materials applications that are not possible with ion-exchanged glasses.

The case of nepheline glass-ceramic appears unique: when the level of potassium in the crystals is sufficiently high, the crystal structure transforms to kalsilite. This transformation is associated with a volume increase of about $10 \%$ and results in very high load to failure. However, this transformation occurs only near the surface where the potassium concentration is the highest. Below exchange is thought to take place in the nepheline structure with a lower volume increase.

In the example presented here, it has been observed that abrasion decreases very significantly the biaxial flexure strength. It is probably because the introduced flaws have a length close to the thickness of the kalsilite layer.

\section{CONCLUSION}

Through examples taken in various aluminosilicate systems, a review of the different IOX mechanisms in glass-ceramics and of the resulting mechanical properties has been presented. Some of these mechanisms (amorphization, crystalline phase change) are not observed with glasses. This illustrates the wide range of possibilities that offer glass-ceramics as compared to conventional glasses.

\section{AUTHOR CONTRIBUTIONS}

GB, Nepheline-b spodumene and b quartz glass-ceramics. $\mathrm{MC}$, b spodumene and b-quartz. MD, low crystallinity glassceramic. PM, b quartz glass-ceramics. PP, X-ray Diffraction Expert and Corresponding Author. CS, b spodumene and glass-ceramics.

\section{ACKNOWLEDGMENTS}

Anne Crochet, Ben Hanson, Yassine Kilali, and Khaled Layouni for, respectively, SEM characterization, microprobe analysis, measurements of mechanical properties and discussion. 


\section{REFERENCES}

Aaldenberg, E. M., Lezzi, P. J., Seaman, J. H., Blanchet, T. A., and Tomozawa, M. (2016). Ion-exchanged lithium aluminosilicate glass: strength and dynamic fatigue. J. Am. Ceram. Soc. 99, 2645-2654. doi:10.1111/jace.14294

Beall, G. H., Karstetter, B. R., and Rittler, H. L. (1967). Crystallization and chemical strengthening of stuffed $\beta$-quartz glass-ceramics. J. Am. Ceram. Soc. 5, 181-190. doi:10.1111/j.1151-2916.1967.tb15077.x

Berthier da Cunha, T., Wu, J. P., Peitl, O., Fokin, V. M., Zanotto, E. D., Iannucci, L., et al. (2007). Mechanical properties and impact resistance of a new transparent glass-ceramic. Adv. Eng. Mater. 9, 191-195. doi:10.1002/adem. 200600237

Dejneka, M., Dutta, I., and Smith, C. (2014). Chemically strengthened low crystallinity black glass-ceramics with high liquidus viscosities. Int. J. Appl. Glass Sci. 5-2, 146-160. doi:10.1111/ijag.12076

Duke, D. A., MacDowell, J. F., and Karstetter, B. R. (1967). Crystallization and chemical strengthening of nepheline glass-ceramics. J. Am. Ceram. Soc. 50, 67-74. doi:10.1111/j.1151-2916.1967.tb15041.x

Fischer, H., De Souza, R. A., Wätjen, A. M., Richter, S., Edelhoff, D., Mayer, J., et al. (2008). Chemical strengthening of a dental lithium disilicate glass-ceramic material. J. Biomed. Mater. Res. A 87, 582-587. doi:10.1002/jbm.a.31798

Gy, R. (2008). Ion exchange for glass strengthening. Mater. Sci. Eng. B 149, 159-165. doi:10.1016/j.mseb.2007.11.029

Glaesemann, G. S., Gross, T. M., Bayne, J. F., and Price, J. J. (2012). "Fractography in the development of ion-exchange cover glass," in Fractography of Glasses and Ceramics VI: Ceramic Transactions, eds J. R. Varner and M. Wightman (Hoboken, NJ: John Wiley \& Sons, Inc.), 85-93. doi:10.1002/ 9781118433010.ch5
Laczka, K., Cholewa-Kowalska, K., Środa, M., Rysz, J., Marzec, M. M., and Łaczka, M. (2015). Glass-ceramics of LAS $\left(\mathrm{Li}_{2} \mathrm{O}-\mathrm{Al}_{2} \mathrm{O} 3-\mathrm{SiO}_{2}\right)$ system enhanced by ion-exchange in $\mathrm{KNO}_{3}$ salt bath. J Non Cryst. Solids 428, 90-97. doi:10.1016/j. jnoncrysol.2015.08.003

Ponsot, I., Dal Mas, G., Bernardo, E., Dal Maschio, R., and Sglavo, V. M. (2014). Double strengthening by ion exchange of sintered nepheline glass-ceramics:a new simplified method. J. Ceram. Process. Res. 15(6), 411-417.

Rodriguez-Carvajal, J. (1993). Recent advances in magnetic structure determination by neutron powder diffraction. Phys. B 192, 55-69. doi:10.1016/09214526(93)90108-I

Tagantsev, D. K. (1999). Decrystallization of glass-ceramics under ion exchange diffusion. J. Eur. Ceram. Soc. 19, 1555-1558. doi:10.1016/S0955-2219(98)00475-0

Takeuchi, Y., Mitachi, S., and Nagase, R. (1997). High strength glass-ceramic ferrule for SC-type single mode optical fiber connector. IEEE Photonics Tech. Lett. 9, 1502-1504. doi:10.1109/68.634722

Varshneya, A. (2010). Chemical strengthening of glass: lessons learned and yet to be learned. Int. J. Appl. Glass Sci. 1, 131-142. doi:10.1111/j.2041-1294.2010.00010.x

Conflict of Interest Statement: The authors declare that the research was conducted in the absence of any commercial or financial relationships that could be construed as a potential conflict of interest.

Copyright (c) 2016 Beall, Comte, Dejneka, Marques, Pradeau and Smith. This is an open-access article distributed under the terms of the Creative Commons Attribution License (CC BY). The use, distribution or reproduction in other forums is permitted, provided the original author(s) or licensor are credited and that the original publication in this journal is cited, in accordance with accepted academic practice. No use, distribution or reproduction is permitted which does not comply with these terms. 